Popular

television

drama

Critical perspectives

\title{
Loto 61
}

\section{JONATHW EAONCLL NOSTEFHEN LACEY}




\section{Popular television drama}

\section{Critical perspectives}

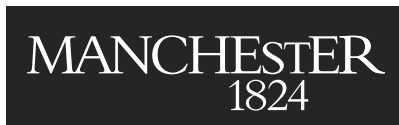

Manchester University Press 
Jonathan Bignell and Stephen Lacey - 9781526125392 Downloaded from manchesterhive.com at $04 / 26 / 2023$ 02:35:34PM 


\section{Popular television drama Critical perspectives}

edited by Jonathan Bignell and Stephen Lacey

Manchester University Press

Manchester 
Copyright (C) Manchester University Press 2005

While copyright in the volume as a whole is vested in Manchester University Press, copyright in individual chapters belongs to their respective authors, and no chapter may be reproduced wholly or in part without the express permission in writing of both author and publisher.

Published by Manchester University Press

Altrincham Street, Manchester M1 7ja, UK

www.manchesteruniversitypress.co.uk

British Library Cataloguing-in-Publication Data

A catalogue record for this book is available from the British Library

Library of Congress Cataloging-in-Publication Data applied for

ISBN 0719069327 hardback

EAN 9780719069321

ISBN 0719069335 paperback

EAN 9780719069338

ISBN 9781526125392 Institutional

First published 2005

$\begin{array}{llllllllllllllllllll}14 & 13 & 12 & 11 & 10 & 09 & 08 & 07 & 06 & 05 & & 10 & 9 & 8 & 7 & 6 & 5 & 4 & 3 & 2\end{array}$

The publisher has no responsibility for the persistence or accuracy of URLs for external or any third-party internet websites referred to in this book, and does not guarantee that any content on such websites is, or will remain, accurate or appropriate.

Typeset in Minion with Rotis Semi-Sans display by Northern Phototypesetting Co Ltd, Bolton 